\title{
Australian Bibliography: An Assay
}

By D. H. BORCHARDT

\begin{abstract}
$\mathrm{A}$ Bibliographic survey of any subject must limit itself to the more important sources of information if it is not to be only a recital of an endless number of bibliographic lists, many of which are either uncritical compilations based on other lists, or are merely enumerations of works consulted for a particular purpose. The term bibliography has been given different meanings by different users, but a careful examination of these varied interpretations will show that only very few bibliographies can be considered independent and self-contained works of scholarship. Too often bibliography is taken as the "natural" handmaiden of other disciplines, in particular of history in its broadest aspects; the creative effort behind the compilation of a thorough and exhaustive bibliography is not appreciated.
\end{abstract}

To present a discursive account of the bibliographies concerned with Australia, comprehensiveness of treatment must be the prime basis of selection. Excluded are all bibliographies or lists on very specialized aspects and those, also, which appeared as appendices to other works. Furthermore, unpublished material except where no suitable bibliography existed in print has been excluded. This survey should therefore be useful as a guide to those who want to establish a basic list of references on Australia. As every practicing reference librarian knows, there is no single true and correct method of finding bibliographic information; not only do reference librarians in different libraries answer the same question by using different sources, but even within the same library one can observe individual bias-not necessarily
Mr. Borchardt is Librarian, University of Tasmania.

in a pejorative sense-towards one or another method of approach.

The review that follows is divided into three major sections: 1) bibliographies which have grown out of an historical approach to Australia; 2) bibliographies of special subjects and, 3) some regional bibliographies, i.e. specialized area bibliographies.

This paper has been greatly facilitated by a recent publication of the Australian Bibliographic Centre at the National Library of Australia, Australian Bibliography and Bibliographical Services, 1960, ${ }^{4}$ a list of 1,289 entries relating to bibliographies compiled in Australia or dealing with Australia. The Centre is in effect the secretariat of the Australian Advisory Council on Bibliographic Services, established in 1956 to plan and recommend its development and coordination. The book is a mere list, arranged by subject, of all known bibliographies of Australian interest. Principal holding libraries are shown, but not always in an exhaustive or reliable manner. While the inclusion of the term "bibliographical services" in the title is unsupported by the contents-there is no description of any services available to anyone or offered by anybody-the list has an interesting appendix showing work in progress at the time of going to press. However, it is not for me to cavil at this very useful compilation without the existence of which it would have taken a great deal longer to write the following pages.

The earliest references to Australia oc- 
cur naturally in the reports of voyages to and through the Pacific. Though the Terra Australis Incognita was not the prime goal for all who went either eastward from the Cape of Good Hope or westward from Cape Horn, it became quite early in the age of cliscoveries an attraction for imaginative sailors of many nations and for a long time the inspiration for many utopian theories. This, however, did not deter some more honest travelers from making attempts at getting precise information on the geography and population of this Terra Australis, or New Holland as some began to call it in the seventeenth century. These voyages were undertaken by many nations and described in several languages. The earliest collective account of voyages to Australia was published in 1756 by De Brosses as Histoire des navigations aux terres australes. ${ }^{14}$ It was translated-and much changed!-by John Callander under the title Terra Australis cognita, issued between 1766 and 1768.15 This collection was followed by Dalrymple's Historical collection of the several voyages and discoveries in the South Pacific ocean, 1770-1771.20 These three collections formed the background of popular knowledge against which the voyages of Captain James Cook stand out in the final act of discovery and description of the eastern coast of the fifth continent. Cook's voyages and works relating to them have received ample bibliographic treatment (Holmes; ${ }^{30}$ Spence $^{45}$ ) and John Beaglehole's edition of the voyages will represent the last word on this subject for many decades to come.

As for other voyages, several admirable collections were issued during the early nineteenth century, among which those by Pinkerton ${ }^{40}$ and by Kerr ${ }^{31}$ are probably the most noteworthy. With the foundation of the Hakluyt Society in 1846 serious interest in scholarly editions of voyages and explorations received the required financial backing, and among the many accounts and reports printed by the Society are numerous works bearing on Australia. ${ }^{32}$

A brief annotated list of Australian voyages is contained in Cox's Reference Guide to the Literature of Travel, 19351949, (11:293-319); ${ }^{17}$ though the notes are often useful it is far from exhaustive.

In practice-and rightly so-bibliographies tend to grow and develop only when they are based on collections of books. These in turn can only be built when a body of literature on a subjectconcrete or abstract-has been created. No wonder, therefore, that we do not find substantial collections of books on Australia until the second half of the nineteenth century, those of Mitchell and of Petherick being undoubtedly the best known. In the context of this essay the Petherick collection is more interesting because Petherick was himself a bibliographer of no mean stature. One of his early major works was the compilation of the Catalogue of the York Gate Library, ${ }^{43}$ (a collection of books on geography, with particular reference to the British colonies, gathered by $S$. W. Silver), representing the first printed catalogue of a collection with a substantial Australian interest. It was first issued in 1882 but the second edition is more useful because of its greater coverage. The York Gate Library is now housed in Adelaide, in the rooms of the Royal Geographical Society of Australia (South Australian branch). Petherick was a collector in his own right, and after a varied and at times distressing career as a bibliographer, bookseller, and agent, sold his collection of Australiana (over fifteen thousand items) to the National Library of Australia in 1911, and at his death in 1917, bequeathed his general library of four thousand volumes to the same institution.

Within Australia the Public Library of New South Wales has for historical reasons been the leader in the coverage of the field of Australiana. Its printed catalogue, Australasian Bibliography 
... Catalogue of Books in the Free Public Library, Sydney (1893), ${ }^{37}$ records all holdings of Australasian interest acquired up to 1888 , the centenary of the foundation of the Australian settlement at Sydney Cove, and marks the beginnings of Australia's own contribution to Australian bibliography. It is, within its limits, an excellent work, based on sound principles and quite a remarkable achievement for so young a country.

One other library collection is worth mentioning in this context. The Royal Commonwealth Society, formerly the Royal Colonial Institute, then the Royal Empire Society-history reflected in terminology!-collected practically all significant publications on the overseas branches of the British Commonwealth. The Subject Catalogue of the Royal Empire Society . . by E. Lewin $(4 \mathrm{v} . ; 1930)^{41}$ contains a mine of information on Australia and can safely be regarded as one of the most useful starting points for general bibliographic information up to about 1930.

The early period of settlement brought in its train a spate of reports from immigrants-free and convict-who described with varying degrees of objectivity the social, political, and economic events of their new home. The most reliable guide to the book production relating to the period $1784-1850$ is I. A. Ferguson's monumental Bibliography of Australia (1941- ; 4v.). ${ }^{23}$ A further volume to cover the period $1850-1900$ is still in preparation. With remarkably few inaccuracies, Ferguson offers not only careful descriptions of all items, arranged by year of publication, but indicates also the principal libraries holding copies.

A somewhat selective and more superficial list was compiled by S. A. Spence under the title $A$ Bibliography of Early Books and Pamphlets Relating to Australia, 1610-1880, 1952,44 with a Supplement issued in 1955 extending the coverage to 1900.

Until the achievement of political in- dependence in the 1850 's, much governmental business in the Australian colonies was subject to debate in the British Parliament. With the increasing economic and political significance of the Australian colonies, this was but natural and the Indexes to the Journals of the House of Commons ${ }^{20}$ for the first half of the nineteenth century must be consulted by those wishing to study the early administrative history of Australia. A list of these references is available in the Dixson Library, Public Library of New South Wales, Sydney.

The later periods of Australian history are not so amenable to exhaustive bibliographic description: the mere quantity of books, pamphlets and documents makes a complete bibliography unmanageable, to say the least. A general Bibliography of Australia, 1901-1935 has been in process in the National Library of Australia, but is still at the preparatory stage, on cards. However, mention must be made of the National Library's Annual Catalogue of Australian Publications, 1937-1960² which includes books on Australia published abroad. Though this list is not exhaustive and is limited to monographs and new serials, it is practically complete for publications printed in Australia, as the National Library receives copies of all Australian publications under the Copyright Act of 1912. As from 1961 it will be replaced by the Australian National Bibliography. An attempt at covering the current output of writings on Australian history is being made in the journal Historical Studies, Australia and New Zealand. ${ }^{28}$

The formation-albeit unconsciousof a national ethos was accompanied by a continuous process of stock-taking. The slow process of weaning from the bosom of Athena Britannica caused Australia to be caught up in the malaise of the Edwardian era without possessing as yet cultural resources which could be considered truly original. For the development of independent scientific work Aus- 
tralia has only of late gathered the necessary resources, and such achievements as she can boast of in the humanities are insufficiently differentiated from the British background. This is an excuse for, rather than an accusation of, the fact that in many respects Australia has only recently begun to produce a quantity of artistic and humanistic material which one could consider characteristic.

For the large field of Australian letters, we possess the most thorough bibliography so far produced in Australia: E. Morris Miller's Australian Literature from its Beginnings to 1935 . . . with Subsidiary Entries to 1938 (1940; 2v.). ${ }^{34}$ Including as it does, biographical notes and critical evaluations of the more important writers as well as some surveys of periods and of forms, this is a unique work; a summing up by a man who is recognized as Australia's leading bibliographer of his day and who was the first professional librarian to be made an Honorary Life Member by the Library Association of Australia. An attempt has been made by F. T. Macartney to extend Morris Miller's Australian literature to include the literary work of Australian writers up to 1950 . His Australian Literature: a Bibliography of 1938 Extended to $1950(1956)^{35}$ reprints parts of Morris Miller's original work (a sad emasculation) and adds information on the subsequent decade, largely adipose without muscle.

Morris Miller's great work was preceded by some minor efforts among which P. Serle's A Bibliography of Australasian Poetry and Verse (1925) ${ }^{42}$ is noteworthy. An effort is being made by Walter Stone to establish a series of bibliographic monographs, mainly in the literary field. Stone is editor-and printer and publisher!-of the series Studies in Australian Bibliography (1954- $\quad)^{48}$ of which eleven numbers have appeared so far, and also produces and edits the journal Biblionews, ${ }^{12}$ organ of the Australian Bookcollectors' Society, which contains numerous bibliographic surveys. It is saddening to reflect that both these worthy enterprises are done with cheap stencils on cheap paper.

While the bibliography of Australian literature is meager in quantity, the field of sociology has received scarcely more extensive treatment. Australia has the reputation of being well advanced in social work and social legislation, and its federal system of government has given much stimulus to legal thought and to political experiments. There is, alas, no very comprehensive bibliography available and as the years roll on it becomes less and less likely that a full-dress bibliography, both historical and critical, of Australian political and sociological thought will be compiled.

The great welding operation which culminated in the proclamation of the Commonwealth of Australia as a federal unit in 1901 was preceded by much pamphleteering and publishing of books for and against federation. Allan Gross's $A t$ tainment: Being a Critical Study of the Literature of Federation, with Bibliography, (1948) ${ }^{27}$ tries to review the political temper of the time. J. D. Holmes's Bibliography on Federation ${ }^{29}$ exists still only in manuscript form in the National Library of Australia.

In 1953 that library issued a roneoed pamphlet, Select Bibliography on Economic and Social Conditions in Australia, 1918-1953,3 which is indeed rather "select," and too brief. The process of government is the subject of Jean Craig's Bibliography of Public Administration in Australia (1850-1947) (1955) ${ }^{18}$ but users should be aware that the work is almost exclusively limited to administrative thought in New South Wales. A survey of The Literature of Australian Government and Politics, by S. R. Davis and G. A. Hughes ${ }^{22}$ was published in the Australian Journal of Politics and History, (1958).

In Australia (which has been blessed with seven parliaments) there is more 
opportunity than in many countries for political leaders to apply social ideals to the practical national way of life. Consequently the Papers and Proceedings of all Australian Parliaments abound with statements concerning the economic and political conditions of the country. The indices to the Parliamentary Papers of the Commonwealth Houses and to the Houses of the six states represent the only general key to this type of publication. Unfortunately, not all of these indices have been adequately or recently consolidated, and the manner of compilation leaves much to be desired-or too much to the ingenuity of the user.

The importance of public inquiries into the administrative behavior of governments and their agents and agencies has long been recognized by all who profess democratic persuasions. A. H. Cole's Finding-list of Royal Commission Reports in the British Dominion $(1939)^{16}$ includes a selected list of such public inquiries held in Australia. An attempt to provide an exhaustive list of them is being made by $D$. H. Borchardt in his Check List of Royal Commissions, Select Committees of Parliament and Boards of Inquiry, of which two parts have appeared so far, one dealing with the Commonwealth of Australia, 1900-1950, (1958), the other with Tasmania, 18561959 (1960); ${ }^{13}$ both provide the names of all commissioners and a synopsis of the recommendations.

The laws of Australia are covered bibliographically as part of the Sweet \& Maxwell Legal Bibliography ${ }^{49}$ of which they form volume six, which appeared in a second edition in 1958 .

Most of the bibliographies discussed so far are retrospective. There are, in addition, several current bibliographies of great importance to the student of Australia since they index periodical literature. The first attempt to cover the social sciences in Australia was made by a Committee on Research in the Social Sciences, itself a section of the Australian Na- tional Research Council. The Committee attained independent status in 1952 as The Social Science Research Council of Australia. Australian Social Science Abstracts $^{11}$ was begun by the original Committee on Research in 1946 and then taken over by the SSRCA. In 1954 the publication of the Abstracts ceased. While there is greater merit in abstracts than in mere indices, the National Library of Australia has over the years greatly improved its index to Australian periodicals and magazines dealing with the social sciences in a broad sense. Known briefly as APAIS, the Australian Public Affairs Information Service ${ }^{8}$ started in 1945; it appears monthly and since 1955 annual cumulations have been issued. It is today the principal source of information for periodical literature on Australian sociology and letters in the widest sense. Its great weakness is the absence of an author index.

Similar ground is covered by the Australian Periodical Index, 1957- $\quad,{ }^{7}$ issued monthly by the Mitchell Library and preceded by the same library's In dex to Periodicals 1944 [ -1955], (1950-1957; 3v.). ${ }^{39}$ The current issues appear as part of the New South Wales Library Bulletin, published by the Public Library of New South Wales. The overlapping of the two periodical indices is regrettable but discussions are in progress to avoid the duplication of work.

A separate indexing service exists for the field of education. The Australian Education Index, (1958- $\quad)^{5}$ is issued by the Australian Council for Educational Research whose librarian is assisted by colleagues from all parts of Australia. It is a cooperative venture and as such is very praiseworthy.

Australia's own creative effort in scientific research has only recently got into full stride. While there is a vast literature on scientific aspects of Australia, and on its botany, geology and zoology in particular, until after the second world war there has not been enough man- 
power or finance to permit substantial research on a competitive basis with other countries. Of the descriptive sciences, geology is covered by a well-known bibliography appended to Sir T. W. E. David's Geology of the Commonwealth of Australia $(1950 ; 3 \mathrm{v}.){ }^{21}$ There also exist some bibliographic surveys of states and smaller regions, usually published by the Geological Surveys of each state. Australian bird life has attracted scientist and amateur alike, and the greater mass of material on this subject has been listed by H. M. Whittell in his The Literature of Australian Birds . . . 16181950 (1954). ${ }^{50}$ A. Musgrave's Bibliography of Australian Entomology, 1775-193036 is the standard work on the literature of Australian insects.

A number of useful lists of the literature of highly specialized subjects appeared from time to time in such scientific journals as the Proceedings of the Linnean Society of New South Wales and elsewhere, but to draw attention to them here would be contrary to the aims of this paper.

Retrospective bibliography is of course not as vital as current coverage. Australian Science Abstracts ${ }^{9}$ was produced between 1922 and 1957 by the Australian and New Zeland Association for the Advancement of Science, from v.17 (1933) on, as part of the Australian Journal of Science. ${ }^{6}$ Since 1957, the head office of the Commonwealth Scientific and Industrial Research Organisation (CSIRO), Melbourne, has issued an Australian Science Index, ${ }^{10}$ which supersedes the $A b$ stracts, and covers all scientific work of Australian interest.

Though various Christian denominations took an early interest in Australia, either with a view to establishing missions to convert the Australian native population or to catering to the felons and convicts who were certainly in need of faith, hope, and charity, it must also be remembered that the early Spanish and Portuguese voyages were made under mandates which included inter alia the obligation to bring Christianity to the Pacific Ocean. As far as can be ascertained there exists a bibliography of mission literature for the Roman Catholic Church only, R. Streit's Bibliotheca missionum: Missions-literatur von Australien und Ozeanien, 1525-1950 (1955). ${ }^{47}$ Arranged chronologically, it is a fine example of biliographic scholarship.

Of the special subject bibliographies which provide a general insight into things Australian, there remains only one which despite its intrinsic significance has not been mentioned earlier simply because it is based on a formal criterion of selection: university research. In a country as thinly populated as Australia, yet supporting no less than ten universities (only two of which are more than a hundred years old) it is perhaps surprising that original academic research should be possible at all, certainly that it should attain international recognition. Yet Australia has made numerous outstanding contributions to the world of learning and her universities have produced many scholars of international renown. In recent years, all Australian universities have begun to issue research reports which give an account of work in progress and frequently list publications by staff members. It is more difficult, however, to find details of earlier research, largely because the university calendars are not as informative as one might wish. To remedy this situation, and to keep in step with bibliographic development in other countries, Mrs. M. J. Marshall compiled a Union list of Higher Degree Theses in Australian University Libraries (1959), ${ }^{33}$ the first Supplement to which was issued in 1961. The base volume lists 3,333 theses submitted since Australian universities began granting higher degrees; unfortunately the list is not complete, as many earlier theses have been lost. Future supplements will keep the list up to date (Continued on page 251) 
Australian Bibliography . . .

(Continued fromt page 212)

and include such earlier theses as may come to light.

Size of area, uneven spread of population: these are the dominant undertones which accompany all statements concerning literature, science, description, general cultural achievement in Australia. None can gainsay their significance. The effect of these two strains is doubly felt when we look for published writings on the separate regions of the Commonwealth. Not even the Department of PostWar Reconstruction, which flourished between 1943 and 1949 (when it became the Department for National Development) succeeded in producing a bibliography for each state when it caused the compilation of the Regional Planning Bibliography (1948-1950) ${ }^{1}$ undertaken by its Regional Planning Division at the request of a conference of Commonwealth and State officers. The regional planning bibliography covers only New South Wales, Victoria, South Australia, Western Australia and Northern Australia, and a supplementary volume, Australia's Vegetation, Forestry and Timber Resources (1948). These bibliographies were intended principally to serve the need for economic planning essential to Australia's development after the second world war, and they are consequently but quite naturally limited to publications dealing with the industrial and agricultural potential of the regions. It is interesting to note that Western Australia is the region best served with bibliographies. F. G. Steere compiled a Bibliography of Books, Articles and Pamphlets Dealing with Western Australia Issued since its Discovery in 1616 (1923). ${ }^{46}$ A supplement with the title Additions to Steere's Bibliography of Western Australia was made in 1924 , but it does not appear to have been printed. In 1953 F. K. Crowley published his Records of
Western Australia, Vol. $1,{ }^{19}$ a huge roneoed volume of almost eleven hundred pages. Clearly, sparsity of population does not necessarily prevent bibliographic work.

A region only recently served by bibliographic treatment is Tasmania. E. D. Flinn's The History, Politics and Economy of Tasmania in the Literature, 1856 $1959(1961)^{24}$ is a reliable and very useful guide to Australia's second oldest state.

For South Australia, T. Gill's Bibliography of South Australia (1886) ${ }^{25}$ is still the only published list of sources, while the only bibliography of New South Wales, issued by its own Public Library under the title Works on New South Wales, comp. . . . under the direction of R. C. Walker, ${ }^{38}$ is of about the same vintage: 1878. However, each state library keeps card indexes of current references to its own state.

In addition there exist a few bibliographies of small areas, e.g., towns, river valleys, etc. which are too specialized to be mentioned here. In general, however, regional bibliography is still largely terra incognita.

It will have been noted that I have not dealt with some major bibliographic enterprises which have not only commanded a great deal of enthusiastic work but some of which have attracted substantial monetary support from government agencies.

However, my aim has been to limit myself to the subject: "Australia-Bibliography." This does not include the practice (and theory) of bibliography in Australia, a practice which has had the benefit of numerous librarians of great ability and perseverance, and which has produced some really first-rate tools. Without these, Australian scholarship would be very seriously hampered. Since they fall outside the scope of this paper I hope to be able to discuss elsewhere and with leisure the full range of "Bibliography, Australian." 


\section{Bibliography}

1. Australia. Department of National Development. Division of Regional Development. A Classified and Selective Bibliography on Australia for Regional Planning Purposes, comp. by KaTHLEEN M. Herberg. Canberra: The Department, 1948-1950. (Roneoed). (Parts 2-3, $5,7-8$ and Supplement only published to date).

2. Australia. National Library. Annual Catalogue of Australian Publications. Nos. 1-25. Canberra: Government printer, 1937-1960. (Superseded, 1961, by Australian National Bibliography).

3. Australia. National Library. Select Bibliography on Economic and Social Conditions in Australia, 1918-1953. [Canberra]: The Library, 1953.

4. Australian Bibliographical Centre. Australian Bibliography and Bibliographical Services. Canberra: Australian Advisory Council on Bibliographical Services, 1960.

5. Australian Education Index. [Melbourne]: ACER, 1957- . No. [1]- . Quarterly.

6. Australian Journal of Science. Sydney: Australian and New Zealand Association for the Advancement of Science, 1938-

$$
\text { . v.l- . }
$$

7. Australian Periodical Index. Sydney: The Library, 1956- . Monthly. (Issued as a supplement to the Monthly Catalogue of the Public Library of New South Wales. Continues the Mitchell Library's Index to Periodicals, item 39.)

8. Australian Public Affairs Information Service: a Subject Index to Current Literature. Canberra: National Library, July 1945- . v.l- . Monthly.

9. Australian Science Abstracts: Supplement to the Australian Journal of Science. 1922-June 1957. v.1-22.

10. Australian Science Index. Melbourne: Commonwealth Scientific and Industrial Research Organization, 1957- . v.[1] . Monthly, with annual cumulations.

11. Australian Social Science Abstracts. [Melbourne]: Australian National Research Council, Committee on Research in the
Social Sciences, Mar. 1946-Nov. 1954. Nos. 1-18.

12. Biblionews: Monthly Letter to Members. [Sydney]: Book Collectors Society of Australia, Apr. 1947- . no.l- .

13. Borchardt, Dietrich Hans. Checklist of Royal Commissions, Select Committees of Parliament and Boards of Inquiry. Cremorne: The Stone Copying Co. v.l, "Commonwealth of Australia, 19001950," 1958; v.2: “Tasmania," 1856-1949, 1960. (Studies in Australian Bibliography, no. 7,10$)$.

14. Brosses, Charles de. Histoire des Navigations aux Terres Australes. 2v. Paris: Durand, 1756.

15. Callander, John. Terra Australis Cognita; or, Voyages to the Terra Australis or Southern Hemisphere, During the Sixteenth, Seventeenth and Eighteenth Centuries. . . . 3v. Edinburgh: Donaldson, 1766-1768.

16. Cole, Arthur Harrison. A Finding List of Royal Commission Reports in the British Dominions. Prepared under the direction of Arthur Harrison Cole, with an introductory essay by HugH McDowell Clokie. Cambridge: Harvard University Press, 1939.

17. Cox, Edward Godfrey. A Reference Guide to the Literature of Travel, Including Voyages, Geographical Descriptions, Adventures, Shipwrecks and Ex. peditions. 3v. Seattle: University of Washington, 1935-1949.

18. Craig, Jean. Bibliography of Public Administration in Australia (1850-1947). With an Introduction by T. H. KewLEY. Sydney: Department of Government and Public Administration, University of Sydney, 1955.

19. Crowley, Francis Keble. The Records of Western Australia. Perth, Publications Committee of the University of Western Australia, 1953- . v.l- .

20. Dalrymple, Alexander. An Historical Collection of the Several Voyages and Discoveries in the South Pacific Ocean. . . 2v. London: The author, 1770-1771.

21. David, Sir Tannatt William Edgeworth. 
The Geology of the Commonwealth of Australia, ed. and much supplemented by W. R. Browne. 3v. London: Arnold [1950].

22. Davis, S. R. and Hughes, Colin A. "The Literature of Australian Government and Politics," Australian Journal of Politics, IV (1958), 107-33.

23. Ferguson, John Alexander. Bibliography of Australia. Sydney: Angus, 1941v.1- . v.l: 1784-1830; v.2: 1831-1838; v.3, 1839-1845; v.4, 1846-1850.

24. Flinn, Elizabeth. The History, Politics and Economy of Tasmania in the Literature, 1856-1959. Hobart: University of Tasmania Library, 1961.

25. Gill, Thomas. Bibliography of South Australia. Adelaide: Government Printer, 1886.

26. Great Britain. Parliament. House of Commons. General Index . . 1801-1852. 3v. London: H.M.S.O.

27. Gross, Alan. Attainment: Being a Critical Study of the Literature of Federation, with Bibliography. Melbourne: Bread and Cheese Club, 1948.

28. Historical Studies: Australia and New Zealand. Melbourne: University Press, 1940 _ . v.1- . Semi-annual.

29. Holmes, John Dashwood. "Bibliography on Federation." 15v. MS in National Library of Australia, Canberra.

30. Holmes, Sir Maurice. Captain James Cook ... a Bibliographical Excursion. London: Edwards, 1952.

31. Kerr, Robert. A General History and Collections of Voyages and Travels, Arranged in Systematic Order. . . 18v. Edinburgh: Blackwood, 1811-1817.

32. Lynam, Edward William O'Flaherty. Richard Hakluyt and His Successors: a Volume Issued to Commemorate the Centenary of the Hakluyt Society. London: The Society, 1946.

33. Marshall, Mary Jacqueline (Meston). Union List of Higher Degree Theses in Australian University Libraries. Hobart: University of Tasmania Library, 1959.

34. Miller, Edmund Morris. Australian Literature from Its Beginnings to 1935: a Descriptive and Bibliographical Survey of Books by Australian Authors in Poetry, Drama, Fiction, Criticism and Anthology with Subsidiary Entries to 1938. 2v. Melbourne: University Press, 1940.

35. Miller, Edmund Morris. Australian Literature: a Bibliography to 1938 Extended to 1950 , ed. with a historical outline and descriptive commentaries by FrEDERICK T. Macartney. Sydney: Angus [1956].

36. Musgrave, Anthony. Bibliography of Australian Entomology, 1775-1930; with Biographical Notes on Authors and Collectors. Sydney: Royal Zoological Society of New South Wales, 1932.

37. New South Wales. Public Library, Sydney. Australasian Bibliography: Catalogue of Books in the Free Public Library, Sydney, Relating to or Published in Australasia. . . . Sydney: Government Printer, 1893. 3 parts in 1 vol.

38. New South Wales. Public Library, Sydney. Works on New South Wales, comp. at the Free Public Library, Sydney, under the direction of R. C. WALkER. . . . Sydney: Government Printer, 1878.

39. New South Wales. Public Library. Mitchell Library. Index to Periodicals 19441955. 3v. Sydney: Public Library of N.S.W., 1950-1957.

40. Pinkerton, John. A General Collection of the Best and Most Interesting Voyages and Travels in All Parts of the World ... Digested on a New Plan. 17v. London: Longman, 1808-1814.

41. Royal Commonwealth Society, London. Subject Catalogue of the Library of the Royal Empire Society, Formerly Royal Colonial Institute, by Evan Lewin. 4v. London: The Society, 1930-1937.

42. Serle, Percival. A Bibliography of Australasian Poetry and Verse, Australia and New Zealand. Melbourne: University Press, 1925.

43. Silver, S. William. Catalogue of the York Gate Library, Formed by S. William Silver; an Index to the Literature of Geography, Maritime and Inland Discovery, Commerce and Colonisation, by Edward Augustus Petherick. 2d ed. London: Murray, 1886.

44. Spence, Sydney A. A Bibliography of Selected Early Books and Pamphlets Relating to Australia, 1610-1880. London: The author, 1952. 
- - - Supplement: and Extension from 1881-1900. 1955.

45. Spence, Sydney A. Captain James Cook, R.N. (1728-1779): a Bibliography of His Voyages, to Which is Added Other Works Relating to His Life, Conduct and Nautical Achievements. Mitcham: The author, 1960.

46. Steere, Francis Grylls. Bibliography of Books, Articles and Pamphlets Dealing with Western Australia Issued Since Its Discovery in 1616. Perth: Government Printer, 1923.

—_. "Additions to Steere's 'Bibliography of Western Australia." " [ Perth: 1924] Typescript.

47. Streit, Robert. Missionsliteratur von Australien und Ozeanien, 1525-1950, begonnen von P. Robert Streit; fortgeführt von P. Johannes Dindinger. Freiburg: Herder, 1955.

48. Studies in Australian Bibliography. Cremorne: Stone Copying Co., 1954- . no. $1-$.
49. [Sweet and Maxwell's] Legal Bibliography of the British Commonwealth of Nations. 2d ed., comp. by W. Harold MaXwell and Leslie F. Maxwell. London: Sweet and Maxwell, 1955- . v. 1 .

50. Whittell, Hubert Massey. The Literature of Australian Birds: a History and a Bibliography of Australian Ornithology. Perth: Paterson Brokensha, 1954.

\section{Be an Early Bookworm!}

Make your reservation early, for the third annual Rare Book Conference on June 15 and 16, at the University of Miami, in Coral Gables, Fla. The topic will be Book Illustration.

Registration fee is $\$ 30.00$, and includes dormitory room and two dinners. Send your reservation and check to Mark M. Gormley, ACRL Executive Secretary, 50 E. Huron St., Chicago 11, before June 1 .

\section{Four Extraordinary Library Sets}

LE VICOMTE DE CHATEAUBRIAND. Oeuvres Completes. 36 volumes. $1 / 2$ leather bindings (slightly scuffed) Paris 1838

$\$ 95.00$

AMBROSE BIERCE. Collected Works. 12 volumes. Ltd. Edition. With 2 pp. ALS from A.B. to Neale

$\$ 160.00$

WILLIAM H. PRESCOTT. Complete Works. 22 volumes. The Monumental AZTEC EDITION. Ltd. to 250 sets.

$\$ 120.00$

JOHN RUSKIN. Complete Works. 39 volumes. The famous LIBRARY EDITION. Bound in full blind-stamped morocco

$\$ 150.00$

\section{IRA J. FRIEDMAN, Inc. \\ Booksellers - - Publishers - - Importers \\ Port Washington, L. I., N. Y.}

Try our outstanding Search Service with your next want list 